\title{
Sex and gender discrimination within EU pension systems
}

Sigrid Leitner, University of Goettingen, Germany

\section{Summary}

Drawing on the philosophical differentiation between sex and gender, this article focuses on structural mechanisms of gender discrimination within European pension systems. For this purpose, the article distinguishes between two dimensions of the gender category: the work behaviour dimension and the care dimension. It is argued that the differentiation between employment and family work on the one hand and specific living arrangements on the other is structurally implemented within old age security systems. All countries have established earnings-related schemes which, to various extents, refer to former earnings and continuous working careers. Many of the earnings-related schemes incorporate family work in one way or another by granting entitlement for the care of children and/or elderly or handicapped people. Most of the schemes are combined with additional benefits for spouses and/or survivors, referring to married heterosexual couples. Only a few countries have additionally established universal pension schemes based on residence instead of employment or family work. The comparative analysis of pension systems in the $15 \mathrm{EU}$ member states gives an idea about national varieties of structural gender differentiation.

\section{Key words}

European Union, gender discrimination, old age security, pension systems, sex discrimination

\section{Résumé}

Partant de la différence philosophique entre «sexe» et "genre», cet article se centre sur les mécanisme structurels de discrimination de genre dans les systèmes de pension européens. L'article distingue dans ce but entre deux dimensions; la dimension du comportement de travail et celle des soins (care). Nous argumentons que la différentiation entre d'une part l'emploi et le travail familial et les arrangements spécifiques de vie de l'autre est mise en œeuvre structurellement dans les systèmes de sécurité pour les personnes âgées. Tous les pays ont établi des système liés aux revenus qui se réfèrent aux niveaux de revenus antérieurs et aux carrières professionnelles. Nombreux sont les systèmes qui,d'une façon ou d'une autre, tiennent compte du travail familial en accordant des droits pour la période de soin des enfants et/ou de parents âgés ou de personnes handicapées. La plupart se combine avec des avantages supplémentaires pour les épouses et/ou les personnes survivantes en référence aux couples hétérosexuels mariés. Seul quelques pays ont de manière complémentaire établi des systèmes de pension universelle basés sur la résidence plutôt que l'emploi ou le travail familial. L'analyse comparative des systèmes de pension dans les 15 Etats membres de l'UE fournit un aperçu des variétés nationales de différence structurelle en termes de genre.

\section{Introduction}

During the last 20 years, various feminist scholars have dealt with the discrimination of 
women within the welfare state. Apart from the question of whether the welfare state could be an instrument for women's emancipation or if state-organized programmes are an obstacle to women's liberation per se since they reproduce patriarchal structures of female subordination, there has been extensive effort to push forward the agenda of gendering welfare state research. One of the central concerns of the debate was to uncover the quantitative as well as the qualitative dimensions of women's discrimination and to reveal that all welfare states - though the degree of discrimination varies enormously - systematically treat women differently from men. On the one hand, average benefit levels of women are lower than those of men (e.g. Pearce, 1978; 1993; Schaffner Goldberg and Kremen, 1990), on the other hand, social security regulations directly or indirectly reflect gendered assumptions about social risk protection (e.g. Sainsbury, 1994; 1999). This structural gender bias of welfare states has by now also been acknowledged within mainstream discussions (e.g. Esping-Andersen, 1996). Nevertheless, the gender dimension is not usually considered as a central category of welfare state research. This paper, in contrast, contributes to the gendering of welfare states and focuses on the systematic analysis of sex and gender discrimination within social security.

Feminist research has been able to identify distinct mechanisms of gender discrimination within welfare states. Barbara Nelson (1990) was the first to show for the United States that the existence of a 'two-channel welfare state' leads to a gender-specific segmentation of benefit recipients. Men are over-represented within social security programmes which grant relatively generous entitlements on the basis of social rights earned by contribution payments. Women, however, are over-represented within means-tested welfare programmes which provide less generous benefits and grant entitlements on the basis of need and social stigma. Linda Gordon (1994) sheds light on the history of restrictive and punitive welfare policies for single mothers and Theda
Skocpol (1995) demonstrated that programmes targeted at men (soldiers/veterans) traditionally provide higher benefits and carry with them less social stigma than programmes targeted at women (mothers).

In continental Europe, the feminist debate has focused on two main topics: the earningsrelated structure of social security systems, together with the traditional division of labour between the sexes, has been identified as the main cause of women's discrimination within these systems. In addition, the privileged treatment of traditional family arrangements, incorporated by the double deal of subsidiarity on the one hand and entitlements for spouses on the other, has been viewed as responsible for maintaining the sexual division of labour (early works: Kickbusch and Riedmüller, 1984; Gerhard et al., 1988). The principle of subsidiarity requires a specific organization of work within the private household: while one person functions as family breadwinner, the other person cares for the family. Only in case of family malfunction does the welfare state step in to substitute either the breadwinner or the family carer. As a consequence, in earnings-related social security schemes the (mostly male) breadwinner is directly entitled to social protection whereas the (predominantly female) family carer derives entitlement only indirectly from her (his) relationship to a breadwinner, a fact which mirrors dependency structures within the family. By granting indirectly-derived benefits to the family worker as well as by limiting the supply of public social services to a minimum, the welfare state helps maintain the traditional division of labour (Langan and Ostner, 1991).

Yet another form of gender-specific relation to the welfare state has been discussed by Scandinavian feminists who detected that women's dependence on the welfare state has an extra dimension. The expansion of the public-service sector led to a significant increase in the number of women employed by the state, thereby shifting women's patriarchal dependence from the husband to the state 
(early works: Holter, 1984; Hernes, 1989). Whereas, traditionally, care work was done by women in the private household, reinforcing their financial dependence on the husband, the Nordic welfare states have made care work public work paid for by the state ${ }^{1}$ and thereby transforming the quality of women's dependence while at the same time maintaining their dependence on a patriarchal institution.

The following analysis mainly stems from feminist research on earnings-related benefit provision as well as on the privileged treatment of traditional family arrangements. It tries to combine and reconceptualize existing findings on the discrimination of women within social security. For this purpose, I draw from the philosophical differentiation between gender and sex and its application for social policy analysis (Leitner, 1999a; 1999b). I will mainly focus on the gender category which includes two analytical dimensions: the work behaviour dimension and the care dimension. I will argue that the differentiation between 'male' and 'female' work behaviour as well as between morally 'right' and 'wrong' care arrangements is structurally implemented within social policy. These structural mechanisms of gender differentiation also work within old age security systems - though to different degrees. A comparative analysis of pension systems in the European Union will give an idea about national varieties of structural gender differentiation.

\section{How to conceptualize sex and gender differences within social security?}

Recent developments in feminist theory urge for a more sensitive use of the central analytical category 'woman'. Afro-American feminists like bell hooks (1984) were the first to raise our consciousness about the differences among women, so when we speak about women we have to keep in mind the broad range of female realities. This concept of differences has forcefully been pushed by constructivist theorists like Judith Butler (1990; 1993). Since every individual is a complex and unique human being, we have to leave behind the old bipolar categories of 'women' and 'men'. These categories are oversimplified concepts which should be replaced by multidimensional thinking. Being a (wo)man has been split into two dimensions: gender, the ascribed social role of (wo)men; and sex, the categorization of humans on the basis of biological characteristics.

\section{The biological dimension}

The biological differentiation uses biologically determined differences to legitimize different treatment of men and women. This kind of sex differentiation is institutionalized within social policy by implementing regulations that refer explicitly to biological sex differences. With regard to pension systems, two types of biological differentiation can be observed across Europe: (a) unequal pension age regulations for men and women and (b) unequal access to survivor pension entitlements for men and women. Both forms of different treatment usually benefit women: traditionally, in many European countries, their pension age has been (is) lower than that of men, and men have been denied access to survivor pensions. Be it that these differentiations were implemented for actuarial reasons or as a result of cultural attributions of gender roles, ${ }^{2}$ sex discrimination results from connecting biological and work behaviour differentiation: all men following 'female' work behaviour are not compensated at all, while women following 'male' work behaviour are recompensed as if they were on 'female' work behaviour. It is this kind of sex discrimination that has been challenged by EU law. As a consequence, most countries equalized the pension age of men and women (see Table 1) mostly by increasing women's pension age, which points to the fact that these reforms have also been driven by the effort to lower the cost of national pension schemes. Article 
Table 1 Pension-age regulations for men and women in the EU

\begin{tabular}{lccccccccccccccc}
\hline & $A$ & $B$ & $D K$ & $S F$ & $F$ & $D$ & $G R$ & $I R$ & $I$ & $L$ & $N L$ & $P$ & $E$ & $S$ & $U K$ \\
\hline Men & 65 & 65 & 67 & 65 & 60 & 65 & 65 & 65 & 65 & 65 & 65 & 65 & 65 & 65 & 65 \\
Women & $60^{\mathrm{a}}$ & $62^{\mathrm{b}}$ & 67 & 65 & 60 & 65 & $60^{\mathrm{c}}$ & 65 & 60 & 65 & 65 & 65 & 65 & 65 & 60 \\
\hline
\end{tabular}

Notes:

a Will be increased to 65 until 2033.

b Will be increased to 65 until 2009.

${ }^{c}$ Has been increased to 65 for those insured from 1.1.1993.

Source: BMA (1999).

119 of the EU Treaty is definitely a hindrance to unequal survivor benefit entitlements which caused a belated installation of widowers' pensions in most of the member states.

It can be summarized that discrimination due to biological differentiation is diminishing within European pension schemes. In the following section, I will focus on the gender category and distinguish between work behaviour differentiation/discrimination and differentiation/discrimination due to care arrangements.

\section{The work behaviour dimension}

Work behaviour differentiation results from the distinction between a public sphere of paid employment and a private sphere of unpaid family work. Structural mechanisms of work behaviour differentiation are implemented within social policy by distinctive schemes for employment and family work respectively. The differentiation is non-discriminatory if both kinds of schemes provide equal protection with regard to benefit levels and the quality of social rights. However, the empirical reality of social policy shows discriminatory characteristics: relatively generous social security schemes operate for employment, whereas family work is insufficiently, or not at all, protected. The structure of a two-channel welfare state with an earnings-related and a means-tested system of benefit provision represents very clearly this kind of gender discrimination: continuous employment in combination with full contribution payments leads to high-level security whereas those in discontinuous employment, part-time employment, and unpaid work are worse off (Lewis, 1992).

Feminist social policy analyses should be aware that discrimination against family work does not automatically induce a discrimination of 'women'. This conclusion can only be drawn in a second analytical step which identifies society's current division of labour between the sexes. If the discrimination of family work corresponds to a traditional sexual division of labour within the welfare state's population, we can speak of an indirectly derived discrimination of women keeping in mind that (a) men doing family work are also affected by structural work behaviour discrimination and that (b) employed men and women without family responsibilities benefit from this discrimination.

\section{The care dimension}

The care dimension presumes that individuals relate to one another. These interdependencies take as many different forms of interpersonal relationships and personal living arrangements as there are: e.g. heterosexual and homosexual partnerships, married and unmarried couples, parent and child relationships, and so on. Discriminating effects result from the privileged treatment of a special kind of reciprocal living arrangement. Thus in general, heterosexual couples - and especially those in the traditional form of marriage are supported by social politics; homosexual partnerships - and in most cases also non- 
married heterosexual partnerships - are not equally protected. Social security systems which do not refer to individuals but to a special kind of care relationship discriminate on the basis of alternative living arrangements.

The 'male-breadwinner-marriage' represents a special example of gender discrimination. This concept combines care and work behaviour differentiation in a unique manner by referring to a heterosexual married couple that follows the traditional sexual division of labour. Idealizing this traditional family arrangement within social policy also means reproducing personal relationships of power and dependence among family members - the more so if done in combination with earningsrelated benefit provision: the husband is employed (full time) and acquires social security entitlements for himself and his dependants, whereas the wife is the family worker and receives social protection only indirectly through her husband.

Old age security schemes refer to different extents to these mechanisms of gender discrimination. All countries established earnings-related schemes, most of them in combination with additional benefit schemes for spouses and/or survivors which refer to married heterosexual couples. Most of the earnings-related schemes incorporate family work in one way or the other by granting entitlements for the care of children and/or elderly or disabled people. In addition, some countries have established universal pension schemes based on residence while others provide minimum income schemes for the elderly based on need. In the following section, the broad range of old age security schemes in the 15 EU-member countries will be analysed to identify variations of gender discrimination across Western Europe.

\section{Mechanisms of gender discrimination within old age security schemes}

Apart from the Netherlands, all of the countries compared established obligatory state-organized employment-related pension schemes, which means institutionalizing work behaviour differentiation within old age security systems. ${ }^{3}$ Work behaviour discrimination plays an important role within employmentrelated pension schemes since they are mostly based on the norm of continuous full-time employment.

\section{Work behaviour discrimination within state-organized earnings-related schemes}

First, access to earnings-related pension entitlements is restricted by specific qualifying conditions (see Table 2). Denmark, for example, excludes people employed for less than nine hours per week, unless they work for more than one employer. Finland denies access to the scheme if the working contract lasts for less than one month, and in Sweden as well as in the United Kingdom (SERPS) low income earners do not have access to the earnings-related scheme. In all countries except Belgium and Denmark a minimum duration of insurance coverage is required to acquire eligibility. Whereas this minimum qualifying period can be as low as three months in France, one year in Finland or three years in Ireland and Sweden, four countries (Austria, Greece, Portugal and Spain) require at least 15 years of coverage.

The establishment of minimum qualifying conditions reduces the number of employed persons entitled to pension rights by excluding those working discontinuously and/or those on low incomes, which are two characteristics of women's labour-market participation across Europe (Luckhaus and Ward, 1996). Those who are entitled are again split into different groups according to the duration of coverage and the level of income when it comes to benefit calculation, since pension formulae reflect the amount of average earnings as well as the length of coverage (see Tables 2 and 3). Some schemes base the earnings-related pension benefit on a percentage of average 
Table 2 Qualifying conditions and maximum number of years considered within state earningsrelated schemes

\begin{tabular}{|c|c|c|}
\hline & Qualifying conditions & Maximum number of coverage years \\
\hline Austria & $\begin{array}{l}15 \text { years of contributions } \\
\text { (or } 25 \text { years of coverage) }\end{array}$ & 45 years \\
\hline Belgium & None & $\begin{array}{l}45 \text { years (men), } 42 \text { years (women; will be } 45 \\
\text { years from 2009) }\end{array}$ \\
\hline Denmark & $\begin{array}{l}\text { Employment of at least } 9 \text { hours } \\
\text { per week or at more than one } \\
\text { employer per week }\end{array}$ & 40 years \\
\hline Finland & $\begin{array}{l}1 \text { year of coverage, access only } \\
\text { if working contract lasts for at } \\
\text { least one month }\end{array}$ & 40 years \\
\hline France & 1 quarter of coverage & 37.5 years (will be 40 years from 2003) \\
\hline Germany & 5 years of coverage & No limit \\
\hline Greece & 15 years of coverage & 35 years \\
\hline Ireland & 156 weeks of paid contributions & Continuous contributions/coverage required \\
\hline Italy & 5 years of contributions & No limit \\
\hline Luxembourg & 120 months of coverage & 40 years \\
\hline Portugal & 15 years of contributions & 40 years \\
\hline Spain & 15 years of contributions & 35 years \\
\hline Sweden & $\begin{array}{l}3 \text { years of coverage, exclusion } \\
\text { of low-income earners }\end{array}$ & No limit \\
\hline United Kingdom & $\begin{array}{l}1 \text { year of contributions plus } \\
\text { coverage for } 25 \% \text { of the working } \\
\text { life (Basic Pension). Only income } \\
\text { above the base amount is counted } \\
\text { for SERPS. }\end{array}$ & $\begin{array}{l}90 \% \text { of working life between } 16 \text { th and } 65 \text { th } \\
\text { (men) or } 60 \text { th (women) year (Basic Pension); } \\
\text { no limit (SERPS) }\end{array}$ \\
\hline
\end{tabular}

earnings during a determined period of the individual's working life (e.g. two of the last four years in Finland, the last five years in Greece, the 10 best years in Portugal, the 15 best years in Austria, the last 15 years in Spain, the 17 best years in France, the 20 best years in the United Kingdom [SERPS]). Other schemes (e.g. Belgium, Germany, Italy, Sweden) refer to average lifetime earnings or lifetime contributions for benefit calculation, while others still grant employment-related benefits without taking into account individual earnings (e.g. Denmark, ${ }^{4}$ Ireland, the United Kingdom [Basic Pension]). Finally, Luxembourg grants a lump-sum benefit calcu- lated independently of previous earnings, but related to years of contribution, whereas lifetime earnings are considered for benefit calculation. The longer the period on which benefit calculations are based, the smaller the benefit base in general. Long calculation periods privilege continuously high-earning labour market careers which can be found more often among men than among women.

For calculating the final benefit, the benefit base is usually related to the number of coverage years. Some countries limit the maximum number of years taken into consideration (e.g. 35 years in Greece and Spain, 37.5 years in France, 40 years in Denmark, Finland, 
Table 3 Calculation of the benefit base within state earnings-related schemes

\begin{tabular}{|c|c|}
\hline Austria & Average earnings during the best 15 years \\
\hline Belgium & Average lifetime earnings \\
\hline Denmark & Employment-related benefit (according to number of hours employed) \\
\hline Finland & $\begin{array}{l}\text { Average earnings during } 2 \text { years of the last } 4 \text { years by eliminating the highest and the } \\
\text { lowest earning year (raised to average earnings during the last } 10 \text { years until 2005) }\end{array}$ \\
\hline France & Average earnings during the 17 best years (raised to 25 best years until 2008) \\
\hline Germany & $\begin{array}{l}\text { Total of individual annual earning points (individual's annual earnings divided by } \\
\text { the annual average earnings of all contributors) }\end{array}$ \\
\hline Greece & Average earnings during the last 5 years \\
\hline Ireland & $\begin{array}{l}\text { Employment-related benefit (according to average amount of contribution weeks per } \\
\text { year) }\end{array}$ \\
\hline Italy & Accumulated lifetime contributions \\
\hline Luxembourg & $\begin{array}{l}\text { Lump-sum benefit (according to number of contribution years) plus average lifetime } \\
\text { earnings }\end{array}$ \\
\hline Portugal & Average earnings during the best 10 of the last 15 years \\
\hline Spain & Average earnings during the last 15 years \\
\hline Sweden & Lifetime contributions \\
\hline United Kingdom & $\begin{array}{l}\text { Employment-related benefit (according to duration of coverage) (Basic Pension) plus } \\
\text { average surplus earnings during the whole working life (SERPS) }\end{array}$ \\
\hline
\end{tabular}

Luxembourg and Portugal, 45 years in Austria and Belgium); other countries do not set any limitation (e.g. Germany, Italy, Sweden and the United Kingdom [SERPS]) or require continuous coverage over most of the individual's working life (Ireland, the United Kingdom [Basic Pension]). The higher the number of years considered, the more a scheme privileges continuous employment careers.

Thus, work behaviour discrimination within earnings-related pension schemes is caused by minimum qualifying conditions which restrict the access to pension schemes; by considering rather long periods of bestearning years for calculating the benefit base; and by referring to long periods of insurance coverage for the final benefit calculations. ${ }^{5}$

Earnings-related schemes may also grant additional credits for unpaid care work which marks a break in their basic organizational logic. Most of the schemes compared consider periods of caring for young children in benefit calculation (see Table 4); only Denmark, Finland, and the United Kingdom (SERPS) do not. The length of the periods credited ranges from a maximum of six months in Greece and Italy, one year in Spain, two years in Belgium, France, Luxembourg and Portugal, three years in Germany, four years in Austria and Sweden, up to 16 years in Ireland and the United Kingdom (Basic Pension).

Only seven of the schemes consider periods of care for close family members (see Table 4). Whereas Austria offers a subsidized optional insurance for family carers, Finland, Germany, Italy, Ireland, Sweden and the United Kingdom (Basic Pension) grant different kinds of pension rights for family care. It is interesting to note that Italy also has a voluntary but subsidized pension scheme for housewives.

Though benefits provided on the basis of caring periods are generally low compared to benefits on the basis of earnings, it has to be acknowledged that including care work within 
Table 4 Credits for child care and family care within state earnings-related schemes

\begin{tabular}{|c|c|c|}
\hline & Credits for child care & Credits for family care \\
\hline Austria & $\begin{array}{l}4 \text { years of coverage for each child } \\
\text { (maximum), benefit based on a fixed } \\
\text { amount }\end{array}$ & Subsidized optional insurance for carers \\
\hline Belgium & 2 years of coverage (maximum) & None \\
\hline Denmark & None & None \\
\hline Finland & None & $\begin{array}{l}\text { Pension rights for carers who receive a } \\
\text { home-care allowance }\end{array}$ \\
\hline France & $\begin{array}{l}2 \text { years of coverage for each child (for } \\
\text { mothers only), plus: pension is increased } \\
\text { by } 10 \% \text { if the insured has reared at least } \\
3 \text { children }\end{array}$ & None \\
\hline Germany & $\begin{array}{l}3 \text { years of coverage for each child, benefit } \\
\text { based on annual average earnings of all } \\
\text { contributors (child care credits will be } \\
\text { extended by the } 2001 \text { reforms) }\end{array}$ & $\begin{array}{l}\text { Coverage of informal carers, benefit } \\
\text { based on } 27-80 \% \text { of annual average } \\
\text { earnings of all contributors (depends on } \\
\text { weekly amount of care provided) }\end{array}$ \\
\hline Greece & $\begin{array}{l}\text { 3-6 months of coverage per child (for } \\
\text { mothers only) }\end{array}$ & None \\
\hline Ireland & $\begin{array}{l}\text { The number of years spent caring for } \\
\text { children under } 16 \text { years of age is } \\
\text { disregarded for the purpose of } \\
\text { calculating the number of qualifying } \\
\text { years for a full pension }\end{array}$ & $\begin{array}{l}\text { The number of years spent caring for } \\
\text { elderly, ill or incapacitated persons is } \\
\text { disregarded for the purpose of calculating } \\
\text { the number of qualifying years for a full } \\
\text { pension }\end{array}$ \\
\hline Italy & $\begin{array}{l}6 \text { months of coverage for each child } \\
\text { (maximum, only for mothers); employed } \\
\text { mothers can alternatively reduce their } \\
\text { pension age by } 4 \text { months per child } \\
\text { (maximum of } 12 \text { months) }\end{array}$ & $\begin{array}{l}1 \text { month of coverage per year for carers } \\
\text { (maximum) }\end{array}$ \\
\hline Luxembourg & 2 years of coverage for each child & None \\
\hline Portugal & 2 years of coverage for each child & None \\
\hline Spain & 1 year of coverage for each child & None \\
\hline Sweden & 4 years of coverage for each child & $\begin{array}{l}\text { Coverage for care of an ill or disabled } \\
\text { child under age } 16\end{array}$ \\
\hline United Kingdom & $\begin{array}{l}\text { Periods spent caring for children under } \\
\text { age } 16 \text { are credited within the Basic } \\
\text { Pension system if at least } 20 \text { contribution } \\
\text { years exist }\end{array}$ & $\begin{array}{l}\text { Periods spent caring for elderly, ill or } \\
\text { incapacitated persons are credited within } \\
\text { the Basic Pension system if at least } 20 \\
\text { contribution years exist }\end{array}$ \\
\hline
\end{tabular}

earnings-related schemes is increasingly becoming an issue in pension policy (Daly, 1997; Lewis, 1998). Crediting care work is an attempt to mitigate mechanisms of work behaviour discrimination within old age security. Although earnings-related norms are not being fundamentally revised, they are nevertheless supplemented by regulations which aim at allowing for a combination of employment and family work. This can be interpreted as a positive first step towards equal treatment of different work behaviour, but it has to be 
Table 5 Old age benefits for spouses and survivors in the EU

\begin{tabular}{|c|c|}
\hline Austria & Survivor: $40-60 \%$ of the deceased's pension (income-tested) \\
\hline Belgium & $\begin{array}{l}\text { Spouse: Additional } 15 \% \text { of the insured's average lifetime earnings } \\
\text { Survivor: } 80 \% \text { of the couple's pension (income-tested) }\end{array}$ \\
\hline Denmark & Survivor: Monetary compensation (income-tested) \\
\hline Finland & Survivor: Percentage of the earnings-related pension of the deceased (income-tested) \\
\hline France & $\begin{array}{l}\text { Spouse: Additional flat-rate supplement (income-tested) } \\
\text { Survivor: } 54 \% \text { of the deceased's pension (income-tested) }\end{array}$ \\
\hline Germany & $\begin{array}{l}\text { Survivor: } 60 \% \text { of the deceased's pension (income-tested) (will be reduced to } 55 \% \text { by } \\
\text { the } 2001 \text { reforms) }\end{array}$ \\
\hline Greece & $\begin{array}{l}\text { Spouse: Flat-rate supplement for dependent spouse } \\
\text { Survivor: } 70 \% \text { ( } 50 \% \text { for future generations) of the deceased's pension }\end{array}$ \\
\hline Ireland & $\begin{array}{l}\text { Spouse: Flat-rate supplement } \\
\text { Survivor: Basic pension of the deceased. If the survivor receives a basic pension on } \\
\text { her/his own, the higher of the benefits is provided }\end{array}$ \\
\hline Italy & Survivor: $60 \%$ of the deceased's pension (income-tested) \\
\hline Luxembourg & $\begin{array}{l}\text { Survivor: } 100 \% \text { of the deceased's lump-sum benefit plus } 75 \% \text { of the deceased's } \\
\text { earnings-related additional benefit (income-tested) }\end{array}$ \\
\hline Portugal & Survivor: $60 \%$ of the deceased's pension \\
\hline Spain & Survivor: $45 \%$ of the deceased's pension \\
\hline Sweden & Survivor: $40 \%$ of the deceased's pension, restricted to 12 months after his/her death \\
\hline United Kingdom & $\begin{array}{l}\text { Spouse: Flat-rate benefit together with the Basic Pension; spouses with a Basic } \\
\text { Pension on their own can top it up to } 60 \% \text { of the partner's Basic Pension } \\
\text { Survivor: Basic Pension of the deceased plus } 50 \% \text { of the deceased's earnings-related } \\
\text { pension from SERPS }\end{array}$ \\
\hline
\end{tabular}

clearly stated that in most countries credits for care are not based on amounts that equal entitlements gained from employment, thereby maintaining gender discrimination though to a lesser degree than before: 'Although credits offer important compensation for time spent undertaking caring work, in the present policy and labour market context such compensation is partial and the crediting system therefore remains a flawed instrument for addressing gender inequality' (Rake, 1999: 234). In most countries, benefits for care are available for both sexes. But still much more often than men, women do the unpaid caring work making the unequal treatment of care predominantly an issue of the indirect discrimination of women within old age security.

\section{Care discrimination within state- organized pension schemes}

Apart from crediting care work within earnings-related schemes, most of the countries compared provide old age benefits for unpaid care work together with state-organized earnings-related benefits in the form of spouse and/or survivor benefits (see Table 5). Contrary to entitlement regulations in earningsrelated schemes, it is not the individual's caring career that qualifies for entitlement (as would be the individual's employment career in the earnings-related schemes), but the family worker's status of being married to a person who is covered by the earnings-related scheme. This indicates a different quality of 
entitlement for family work since entitlement does not result from direct but indirect social rights.

Additional benefits for spouses of persons who are entitled to a state earnings-related pension are granted in Belgium, France, Greece, Ireland and the United Kingdom (Basic Pension). Old age benefits for survivors of persons who were entitled to an earningsrelated pension exist in all EU-member states. Usually, the survivor benefit amounts to a percentage of the deceased's pension benefit. The exceptions here are Denmark, where the survivor's pension was substituted by a monetary compensation in 1992, and Sweden, where survivor pensions are restricted to a 12 -month period. Those benefits targeting married family workers reflect the norm of heterosexuality combined with the institution of marriage, thus discriminating on the basis of alternative sexual orientation and alternative forms of living together.

Moreover, spouse and survivor benefits subsidize and therefore maintain family arrangements which are based on the (traditional) division of labour between the sexes. In most countries, benefits are granted regardless of whether the family worker has been fulfilling her (his) obligations or not, since marriage is taken as sufficient indication of how labour is divided within the private household, namely along traditional lines. This is even explicitly formulated in some countries, for example in Greece, where widowers are only entitled to survivor benefits in case of invalidity and material dependence on the deceased wife. Some countries require an income test to determine benefit provision for spouses and survivors, thus controlling to a certain extent whether the (traditional) division of labour between the sexes has been in place.

Hence, old age benefits for unpaid care work are provided in two distinct ways. On the one hand, credit for care may be granted within the employment-related scheme which has the advantage of disregarding the carer's (reciprocal) living arrangement and the disadvantage of worse benefit quality compared to earnings-related benefit calculation. On the other hand, benefits may be granted to married (heterosexual) family workers together with earnings-related schemes, which indicates care discrimination but also work behaviour discrimination since benefits are generally lower than the earnings-related pension benefit of the family breadwinner and entitlements are indirectly derived. Two statements summarize this part of the analysis: first, unpaid care work results in lower quality benefits; and second, unpaid care work within marriage is better off than that outside marriage.

\section{Universal and means-tested schemes}

Only a few countries have established universal pension schemes which provide individualized benefits regardless of care arrangements. Moreover, universal pension benefits are based on the duration of residence, thus neglecting work behaviour differentiation. Such schemes can be found in Denmark, Finland, the Netherlands and Sweden (see Table 6). It has to be noted that only in the Netherlands is no income-test required for benefit entitlement.

The other European countries - with the exceptions of Austria and Germany - offer means-tested minimum income provisions for the elderly which constitute a last resort for all those not sufficiently protected by earningsrelated and/or family worker benefits. Meanstested benefits do not per se lead to gender discrimination. Nevertheless, it can be argued that the clientele of such benefits is probably restricted to people who failed in the labour market or who were long-term family workers. Thus, means-tested benefits reproduce work behaviour discrimination, since they are typically of very low quality.

\section{A comparative interpretation}

What conclusions can be drawn from this 
Table 6 Old age benefits based on residence and/or need in EU

\begin{tabular}{|c|c|}
\hline Austria & General welfare \\
\hline Belgium & Means-tested flat-rate benefit \\
\hline Denmark & $\begin{array}{l}\text { Full pension requires } 40 \text { years of residence (minimum: } 3 \text { years) } \\
\text { Flat-rate benefit varies with the duration of residence, } 1 / 40 \text { of full rate for each year } \\
\text { of residence. Benefit is reduced in case of high income }\end{array}$ \\
\hline Finland & $\begin{array}{l}\text { Full pension requires } 40 \text { years of residence (minimum: } 3 \text { years) } \\
\text { Means-tested flat-rate benefit varies with the duration of residence, 1/40 of full rate } \\
\text { for each year of residence }\end{array}$ \\
\hline France & Means-tested allowance up to a basic minimum \\
\hline Germany & General welfare \\
\hline Greece & Means-tested flat-rate benefit \\
\hline Ireland & Means-tested flat-rate benefit \\
\hline Italy & Means-tested minimum income \\
\hline Luxembourg & Means-tested minimum income if 10 years of residence during the last 20 years \\
\hline Netherlands & $\begin{array}{l}\text { Full pension requires } 50 \text { years of residence } \\
\text { Flat-rate benefit varies with the duration of residence, } 2 \% \text { of full flat-rate for each } \\
\text { year of residence }\end{array}$ \\
\hline Portugal & Means-tested flat-rate benefit \\
\hline Spain & Means-tested flat-rate benefit if 10 years of residence \\
\hline Sweden & $\begin{array}{l}\text { Full pension requires } 40 \text { years of residence (minimum: } 3 \text { years) } \\
\text { Income-tested flat-rate benefit varies with the duration of residence, } 1 / 40 \text { of full rate } \\
\text { for each year of residence }\end{array}$ \\
\hline United Kingdom & Means-tested flat-rate benefit if 10 years of residence during the last 20 years \\
\hline
\end{tabular}

structural analysis of gender discrimination within old age security systems in the European Union? How do work behaviour and care discrimination vary across Europe? The analysis given allows a classification of the compared pension schemes according to their degree of gender discrimination. Therefore, categories of low, medium and high work behaviour discrimination have been defined and the schemes were attributed accordingly (see Table 7).

The category 'Access' reflects the minimum period of coverage required by a pension scheme to reach eligibility for pension entitlement. The 15 schemes under consideration fall clearly into three groups: those with high requirements of 15 years of coverage; those with low-level conditions of up to five years of coverage; and those in between the two groups (compare Table 2). Under the heading 'Benefit base', the schemes are classified according to the length of the period during which income averages - which build the base for benefit calculation - are considered. Again, two contrasting poles can be distinguished: one group of schemes bases benefit calculations on average lifetime income, which represents a high degree of work behaviour discrimination, whereas another group of schemes is hardly discriminating in this regard. The remaining schemes show time periods between 10 and 17 years. Luxembourg is the only critical case as it combines lifetime earnings with a lump-sum benefit which does not refer to former income at all. This mixture of highly and less discriminating 
Table 7 Classification scheme concerning the degree of work behaviour discrimination (high-medium-low) within state earnings-related pension schemes

\begin{tabular}{|c|c|c|c|}
\hline & Low discrimination & Medium discrimination & High discrimination \\
\hline Access & $\begin{array}{l}\text { Minimum qualifying } \\
\text { condition of up to } 5 \text { years: } \\
\text { B, DK, SF, F, D, IR, I, S, } \\
\text { UK (SERPS) }\end{array}$ & $\begin{array}{l}\text { Minimum qualifying } \\
\text { condition of more than } \\
5 \text { but less than } 15 \text { years: } \\
\text { L, UK (Basic Pension) }\end{array}$ & $\begin{array}{l}\text { Minimum qualifying } \\
\text { condition of } 15 \text { years: } \\
\text { A, GR, P, E }\end{array}$ \\
\hline Benefit base & $\begin{array}{l}\text { Consideration of average } \\
\text { earnings during at most } \\
5 \text { years: } \\
\text { DK, SF, GR, IR, UK } \\
\text { (Basic Pension) }\end{array}$ & $\begin{array}{l}\text { Consideration of average } \\
\text { earnings during at least } \\
10 \text { and at most } 17 \text { years: } \\
\text { A, F, (L), P, E }\end{array}$ & $\begin{array}{l}\text { Consideration of average } \\
\text { lifetime earnings: } \\
\text { B, D, I, S, UK (SERPS) }\end{array}$ \\
\hline Number of years & $\begin{array}{l}\text { Benefit calculation } \\
\text { considers a maximum of } \\
35 \text { to } 40 \text { contribution } \\
\text { years: } \\
\text { DK, SF, F, GR, L, P, E }\end{array}$ & $\begin{array}{l}\text { Benefit calculation } \\
\text { considers a maximum of } \\
45 \text { years of contribution } \\
\text { or coverage: } \\
\text { A, B, UK (Basic Pension) }\end{array}$ & $\begin{array}{l}\text { Benefit calculation } \\
\text { considers more than } \\
45 \text { years: } \\
\text { D, I, (IR), S, UK (SERPS) }\end{array}$ \\
\hline Child care & $\begin{array}{l}\text { Schemes which consider } \\
\text { up to } 16 \text { years of child } \\
\text { care: } \\
\text { IR, UK (Basic Pension) }\end{array}$ & $\begin{array}{l}\text { Schemes which consider } \\
\text { between } 2 \text { and } 4 \text { years of } \\
\text { child care: } \\
\text { A, B, F, D, L, P, S }\end{array}$ & $\begin{array}{l}\text { Schemes which do not or } \\
\text { hardly consider child } \\
\text { care: } \\
\text { DK, SF, GR, I, E, UK } \\
\text { (SERPS) }\end{array}$ \\
\hline Family care & $\begin{array}{l}\text { Schemes which consider } \\
\text { family care to a } \\
\text { remarkable degree: } \\
\text { SF, D, IR, S, UK (Basic } \\
\text { Pension) }\end{array}$ & $\begin{array}{l}\text { Schemes which consider } \\
\text { family care to a minimal } \\
\text { degree: } \\
\text { A, I }\end{array}$ & $\begin{array}{l}\text { Schemes which do not } \\
\text { consider family care: } \\
\text { B, DK, F, GR, L, P, E, UK } \\
\text { (SERPS) }\end{array}$ \\
\hline
\end{tabular}

elements in the Luxembourg pension scheme places it in the middle group (compare Table 3). The category 'Number of years' indicates the degree to which a certain scheme privileges long periods of insurance coverage. Low discrimination is proffered by schemes which restrict benefit calculations to a maximum of 35-40 coverage years. This allows for insurance spells of a minimum of $10-15$ years. The medium cluster comprises schemes which consider a maximum of 45 years of coverage. Finally, the highest degree of discrimination is found in schemes which consider the entire working life. The Irish pension scheme was added to this group because it requires continuous contribution payments over the whole insurance period. Yet it has to be noted that the Irish scheme does not require coverage over the whole working life (compare Table 2 ). The classification scheme further tries to capture the degree to which care work is recognized by the state earnings-related pension schemes. The category 'Child care' distinguishes between highly discriminating schemes which do not or hardly consider periods of child care for benefit calculation; between schemes which consider child care to a noticeable degree; and finally, schemes with extensive consideration of child-care periods (compare Table 4). Similarly, the category 'Family care' comprises a highly discriminating group of schemes which do not consider periods spent caring for family members at all. These are followed by schemes which consider family care to a minimal degree and others which have developed more comprehensive structures recognizing family-care periods for pension purposes (compare Table 4).

In addition, for the following analysis, care discrimination (which is the other dimension 
Table 8 Work behaviour and care discrimination in universal pension schemes

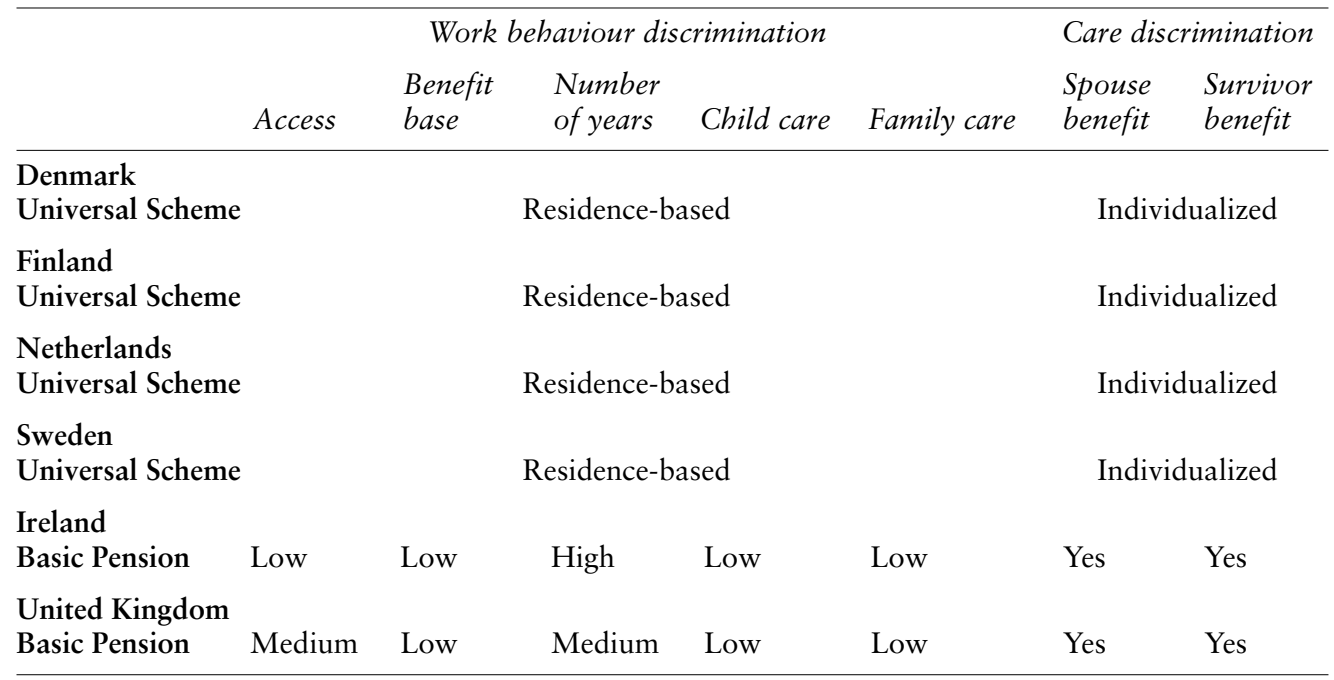

of gender discrimination) is transformed into a dichotomous variable. In this sense, care discrimination takes place when a pension scheme comprises survivor and/or spouse benefits (compare Table 5).

For the comparative interpretation which aims at grouping pension schemes according to their structural profile of gender discrimination, I will, in a first step, follow the wellknown categories of Beveridge-type systems and Bismarck-type systems. There are six European countries with Beveridge-type pension systems. They combine universal or basic pension schemes with earnings-related supplementary schemes. ${ }^{6}$ Comparing their universal schemes (see Table 8), we see, as a first homogeneous group, the Netherlands together with the three Scandinavian countries. Their universal schemes are non-discriminatory in both the work behaviour and the care dimension since they refer to residence instead of work as well as to individuals instead of family status. The principle of universality 'fundamentally focuses on the individual legal claim [...]. If this principle were to be fully implemented, complete gender neutrality concerning coverage would exist in such an old-age security scheme' (Döring et al., 1994: 3). Following this analysis, a second group of 'universal' pension schemes is formed by Ireland and the United Kingdom. Their basic pension schemes are based on employment instead of residence, but work behaviour discrimination within the basic pension schemes is low since they do not refer to former earnings and since care work is generously credited within the scheme. In contrast to the first group of universal schemes, family work is taken as a basis for benefits paid to spouses and survivors which indicates care discrimination and, therefore, contradicts the principle of universality. Hence, a first cluster of six (quasi) universal pension schemes can be identified which - besides the contradictions named above - signal a high degree of gender neutrality. ${ }^{7}$

In a second step, the state earnings-related schemes of the Beveridge-type pension systems are analysed alongside the Bismarck-type pension systems. In contrast to universal schemes, entitlements in earnings-related schemes are earned instead of granted. 'In the process of drawing boundaries around how pension entitlements can be earned, certain forms of work are validated over others' (Rake, 1999: 224). Usually employment generates entitlements, 
Table 9 Work behaviour discrimination in earnings-related schemes

\begin{tabular}{|c|c|c|c|c|c|}
\hline & Access & Benefit base & Number of years & Child care & Family care \\
\hline $\begin{array}{l}\text { Denmark } \\
\text { ATP-Scheme }\end{array}$ & Low & Low & Low & High & High \\
\hline $\begin{array}{l}\text { Finland } \\
\text { ATP-Scheme }\end{array}$ & Low & Low & Low & High & Low \\
\hline Austria & High & Medium & Medium & Medium & Medium \\
\hline France & Low & Medium & Low & Medium & High \\
\hline Greece & High & Low & Medium & High & High \\
\hline Luxembourg & Medium & Medium & Low & Medium & High \\
\hline Portugal & High & Medium & Low & Medium & High \\
\hline Spain & High & Medium & Medium & High & High \\
\hline Belgium & Low & High & Medium & Medium & High \\
\hline Germany & Low & High & High & Medium & Low \\
\hline Italy & Low & High & High & High & Medium \\
\hline $\begin{array}{l}\text { Sweden } \\
\text { ATP-Scheme }\end{array}$ & Low & High & High & Medium & Low \\
\hline $\begin{array}{l}\text { United Kingdom } \\
\text { SERPS }\end{array}$ & Low & High & High & High & High \\
\hline
\end{tabular}

whereas care work does not or if it does then at a considerably lower level. But entitlements earned due to employment (contribution payments) differ according to income levels (amount of contribution payments) and continuity of employment (duration of contribution payments). The stronger the link to lifetime-earnings and the higher the number of years taken into consideration for benefit calculation, the more severely care work is penalized by the scheme. Following this causal argument, at least three groups of earningsrelated pension schemes can be distinguished (see Table 9). First, we see the Danish and the Finnish schemes, both of which are low discriminatory, though not universal, as access is restricted to the employed, and not quasi-universal since care work is not (DK) or only partly (SF) credited. For those with access to the schemes, this lack of recognition of care work is counterbalanced by the relatively small number of years necessary to be considered for benefit calculation.
A second group is made up by the Belgian, German, Italian, Swedish (ATP), and British (SERPS) earnings-related schemes. All of these are rather easily accessible but link benefits to average lifetime earnings. Moreover, they consider - with the exception of the Belgian scheme - more than 45 years of coverage for benefit calculation. This highly discriminatory pattern is reinforced by the lack of care work recognition within the Belgian, the Italian as well as in the British (SERPS) scheme. In contrast, the German and the Swedish (ATP) scheme mitigate work behaviour discrimination through relatively generous recognition of care work which brings them close to the medium discriminatory level.

The third cluster to be identified comprises the remaining six schemes. This group is the most heterogeneous and, therefore, it challenges the analysis. The schemes are characterized by high barriers to access - with the exception of the Luxembourgian and especially the French scheme - and medium levels 
Table 10 Clustering European pension schemes

\begin{tabular}{ll}
\hline Clusters & Pension schemes \\
\hline Gender neutrality & (a) DK, SF, NL, S \\
Low discrimination & (b) IR, UK (Basic Pension) \\
Medium discrimination & (a) DK (ATP), S (ATP) \\
High discrimination & (b) SF (ATP) \\
& (a) A, F, D, L, P \\
\hline
\end{tabular}

of discrimination in the categories 'Benefit base', 'Number of years', and 'Child care'. Only the Greek and Spanish schemes deviate to a remarkable degree since they nearly completely lack recognition of care work and consider up to 45 years of insurance coverage.

If we add the dimension of care discrimination to the above four clusters, we get a slightly altered, but integrated picture (see Table 10). The gender neutrality cluster contains two subgroups, the second of which (b) shows care discrimination whereas the first (a) does not. The low discrimination cluster is similarly split. Whereas Finland does provide survivor benefits, Denmark does not. Interestingly, Sweden has to be grouped with Denmark since its earnings-related scheme does not contain care discrimination and the pension provisions for care work are comparably high, so that they counterbalance the strong link to average lifetime earnings and long contribution periods. The medium discrimination cluster as well as the high discrimination cluster remain nearly unchanged since all of these schemes show care discrimination. Besides the Swedish case discussed above, there is only one exception: due to the relatively generous recognition of care work, Germany was taken out of the high discrimination cluster and added to the first subgroup (a) of the medium discrimination cluster.

After all the details about the different pension schemes and how they institutionalize mechanisms of gender discrimination, one question remains to be answered: What would be the preferable country for women's old age security? This poses a problem since a country's old age security system represents a mixture of different pension schemes which includes a public/private mix as well as different income provisions from state-organized schemes. On the one hand, pension systems that encourage private provision will tend to favour men over women, as will earningsrelated public pensions. On the other hand, universal schemes and flat-rate benefits will tend to equalize men's and women's incomes in retirement (Hutton and Whiteford, 1994: 206-7).

Following Jay Ginn and Sara Arber (1992: 258-9), three models of pension systems can be distinguished in Western Europe: the residual model, the income security model, and the basic security model. The residual model includes the United Kingdom and Ireland 'countries where the minimum pension is inadequate and conditional on the contribution record' and where occupational and private pension schemes top-up the earningsrelated benefits of those in better jobs. In the income security model, state-organized earnings-related schemes constitute the main element of the old age security system. Here we find the Continental and the Southern European countries: Austria, Germany, Belgium, France, Luxembourg, Greece, Italy, Spain, and Portugal. Finally, the basic security model provides a basic pension to all citizens regardless of their work record and in addition, state earnings-related or occupational pension schemes play an important role for income security in old age. The model comprises the Scandinavian countries and the Netherlands. Ginn and Arber found 'that those who are for any reason disadvantaged in employment, especially women with domestic 
responsibilities, are more likely to receive an adequate pension in their own right where the pension system approximates to the "basic security" model (such as Denmark) rather than the "income security" (Germany) or "residual” (UK) model' (1992: 268). Thus, for women with typically female labour-market careers, the countries with universal pension schemes would provide best in old age; above all Denmark, since links between earnings and pension income are weak there. However, women with continuous full-time careers in well-paid jobs would benefit more from the income security or the residual model since benefits are higher in earnings-related schemes than in universal schemes (Hutton and Whiteford, 1994). Lastly, women without (or with a small) independent pension income would be better off in countries with survivor benefit schemes, but only if they were married, otherwise the universal schemes would be the better choice. Therefore the conclusion picks up the starting point which was the differences among women. What we choose as the preferred old age security system for women depends on which subgroup of women we are talking about. It depends on their work behaviour: whether they are employed or family carers, whether they are continuously or discontinuously employed, whether they are employed part time or full time and how much they earn from employment. It also depends on women's care arrangements: whether they are married or widowed, single or living in alternative partnerships and alternative household arrangements.

\section{Acknowledgements}

This paper is based on a presentation given at the SPA-Study Day 'Women, Risk, and Social Policy' (4 March 2000 at the London School of Economics). I am grateful for comments which arose from the discussion there. I especially wish to thank Jay Ginn for her most valuable suggestions. I am also indebted to the anonymous referees who provided useful advice for revising the first draft of the paper. Lastly, I cordially thank Elisa Chuliá for her comments and Angelika Maser for her linguistic support.

\section{Notes}

1 Norway is an exception with regard to public child-care provision (Leira, 1994).

2 Because women have to juggle the double burden of employment and family work - it is argued - they should be rewarded by lowering their pension age; and because women are hindered in gaining individual pension rights due to their family work responsibilities - it is argued they should receive a survivor pension after the family breadwinner's death (Luckhaus and Ward, 1996).

3 The Netherlands did not formally establish a state-organized employment-related pension scheme, but more than $95 \%$ of workers are covered by earnings-related pension schemes, mainly through obligatory collective labour agreements.

4 It has to be noted that in Denmark benefits are based on the number of hours employed, which discriminates against part-time employment.

5 For empirical evidence, see e.g. Rake (1999) who compares Britain, France and Germany with respect to women's and men's income in old age.

6 Those earnings-related schemes may be stateorganized or private occupational schemes; some countries have both. The analysis excludes private schemes. It can be supposed, though, that private schemes reinforce inequalities between men and women (Hutton and Whiteford, 1994).

7 It should be noted that those universal schemes do not automatically provide a sufficient minimum income (Döring et al., 1994). Hutton and Whiteford (1994) even suggest that a high degree of gender equality in terms of retirement income is closely linked to low benefit levels.

\section{References}

BMA (Bundesministerium für Arbeit und Sozialordnung) (ed.) (1999) Euroatlas. Soziale Sicherheit im Vergleich. Bonn: BMA (Referat Öffentlichkeitsarbeit). 
Butler, J. (1990) Gender Trouble: Feminism and the Subversion of Identity. London: Routledge.

Butler, J. (1993) Bodies that Matter: On the Discursive Limits of 'Sex'. London: Routledge.

Daly, M. (1997) 'Welfare States under Pressure: Cash Benefits in European Welfare States over the Last Ten Years', Journal of European Social Policy 7 (2): 129-46.

Döring, D., Hauser, R., Rolf, G. and Tibitanzl, F. (1994) 'Old-age Security for Women in the Twelve EC Countries', Journal of European Social Policy 4 (1): 1-18.

Esping-Andersen, G. (ed.) (1996) Welfare States in Transition. National Adaptations in Global Economies. London: Sage.

Gerhard, U., Schwarzer, A. and Slupik, V. (eds) (1988) Auf Kosten der Frauen. Frauenrechte im Sozialstaat. Weinheim/Basel: Beltz Verlag.

Ginn, J. and Arber, S. (1992) 'Towards Women's Independence: Pension Systems in Three Contrasting European Welfare States', Journal of European Social Policy 2 (4): 255-77.

Gordon, L. (1994) Pitied but not Entitled. Single Mothers and the History of Welfare 1890-1935. New York: The Free Press.

Hernes, H. M. (1989) Wohlfahrtsstaat und Frauenmacht. Essays über die Feminisierung des Staates. Baden-Baden: Nomos.

Holter, H. (ed.) (1984) Patriarchy in a Welfare Society. Olso: Universitetsforlaget.

hooks, b. (1984) Feminist Theory: from Margin to Center. Boston, MA: South End Press.

Hutton, S. and Whiteford, P. (1994) 'Gender and Retirement Incomes: a Comparative Analysis', in S. Baldwin and J. Falkingham (eds) Social Security and Social Change. New Challanges to the Beveridge Model, pp. 199-215. London: Harvester Wheatsheaf.

Kickbusch, I. and Riedmüller, B. (eds) (1984) Die armen Frauen. Frauen und Sozialpolitik. Frankfurt/Main: Suhrkamp.

Klammer, U. (1997) Alterssicherung in Italien. Eine institutionelle, theoretische und empirische Analyse. Berlin: Duncker \& Humblot.

Langan, M. and Ostner, I. (1991) 'Geschlechterpolitik im Wohlfahrtsstaat: Aspekte im internationalen Vergleich', Kritische Justiz 24 (3): 302-17.

Leira, A. (1994) 'Erwerbstätige Mütter und Wohlfahrtsstaaten. Konzepte von Mutterschaft: Mütter als Erwerbende und Betreuende', in E. Appelt and G. Neyer (eds) Feministische Politikwissenschaft, pp. 159-82. Wien: Verlag für Gesellschaftskritik.
Leitner, S. (1999a) Frauen und Männer im Wohlfahrtsstaat. Zur strukturellen Umsetzung von Geschlechterkonstruktionen in sozialen Sicherungssytemen. Wien: Lang.

Leitner, S. (1999b) 'Implementing the Philosophical Differentiation between Gender and Sex. A Gainful Feminist Approach towards Structural Analyses of Social Policy', paper presented at the international and interdisciplinary conference 'Gender and Markets in the Reconstruction of European Welfare States' (July), University of Bremen.

Lewis, J. (1992) 'Gender and the Development of Welfare Regimes', Journal of European Social Policy 2 (3): 159-73.

Lewis, J. (ed.) (1998) Gender, Social Care and Welfare State. Restructuring in Europe. Aldershot: Ashgate.

Luckhaus, L. and Ward, S. (1996) 'Gleiche Rentenansprüche für Männer und Frauen: eine realistische Perspektive?', in A. Bosco and M. Hutsebaut (eds) Sozialer Schutz in Europa. Veränderungen und Herausforderungen, pp. 167-94. Marburg: Schüren.

Nelson, B. (1990) 'The Origins of the Two-channel Welfare State: Workmen's Compensation and Mother's Aid', in L. Gordon (ed.) Women, the State, and Welfare, pp. 123-51. Madison: The University of Wisconsin Press.

Pearce, D. (1978) 'The Feminization of Poverty: Women, Work and Welfare', The Urban and Social Change Review 2 (1+2): 28-36.

Pearce, D. (1993) 'Something Old, Something New: Women's Poverty in the 1990s', in S. Matteo (ed.) American Women in the Nineties. Today's Critical Issues, pp. 79-97. Boston, MA: Northeastern University Press.

Rake, K. (1999) 'Accumulated Disadvantage? Welfare State Provision and the Incomes of Older Women and Men in Britain, France and Germany', in J. Clasen (ed.) Comparative Social Policy: Concepts, Theories and Methods, pp. 220-45. Oxford: Blackwell.

Sainsbury, D. (ed.) (1994) Gendering Welfare States. London: Sage.

Sainsbury, D. (1999) Gender and Welfare State Regimes. Oxford: Oxford University Press.

Schaffner Goldberg, G. and Kremen, E. (eds) (1990) The Feminization of Poverty. Only in America? New York: Greenwood Press.

Skocpol, T. (1995) Protecting Soldiers and Mothers. The Political Origins of Social Policy in the United States. Cambridge, MA: Harvard University Press. 